JANETTA NIEMANN

MALGORZATA JĘDRYCZKA

JOANNA MAJKA

MAREK MRÓWCZYŃSKI

JOANNA KACZMAREK

DOROTA WEIGT

Uniwersytet Przyrodniczy w Poznaniu, Katedra Genetyki i Hodowli Roślin

Kierownik Tematu: dr inż. Janetta Niemann Uniwersytet Przyrodniczy w Poznaniu, Katedra Genetyki

i Hodowli Roślin, ul. Dojazd 11,60-632 Poznań, tel. 61-8487758, e-mail: niemann@up.poznan.pl

Prace zostały wykonane $w$ ramach badan podstawowych na rzecz postępu biologicznego w produkcji roślinnej na podstawie decyzji Ministra Rolnictwa $i$ Rozwoju Wsi nr HOR.hn.802.16.2018, Zadanie 54.

\title{
Introdukcja genów odporności na choroby i owady oraz męskiej sterylności z pokrewnych gatunków rodzaju Brassica do rzepaku (Brassica napus L.)
}

\section{Introduction of disease and pest resistance genes and male sterility from Brassica relatives to rapeseed (Brassica napus $\mathbf{L}$.)}

Słowa kluczowe: fluorescencyjna hybrydyzacja in situ (FISH), geny odporności, krzyżowanie, markery ISSR, mieszańce Brassica, rzepak

Realizowane zadanie badawcze dotyczy poszerzenia zakresu zmienności cech istotnych z punktu widzenia użytkowego wykorzystania rzepaku ozimego. Szczególne znaczenie mają cechy decydujące o odporności rzepaku na stresy biotyczne (choroby grzybowe - sucha zgnilizna kapustnych i mączniak, odporność na owady — śmietka kapuściana, mszyce i pchełka ziemna) oraz męska sterylność, jako niezmiernie istotna przy wytwarzaniu odmian mieszańcowych. W związku z powyższym celem prowadzonych badań $\mathrm{w}$ roku 2018 było otrzymanie pokolenia $\mathrm{F}_{2} \mathrm{BC}_{2} \mathrm{z}$ krzyżowań wykonanych w poprzednim roku badań, oszacowanie odporności na szkodniki i choroby grzybowe komponentów rodzicielskich i mieszańców pokolenia $\mathrm{F}_{3} \mathrm{i}_{4} \mathrm{~F}_{4}$, potwierdzenie mieszańcowego charakteru roślin pokolenia $\mathrm{F}_{2}$ przy pomocy techniki FISH oraz określenie 
zróżnicowania genetycznego mieszańców metodą ISSR, a także identyfikacja sekwencji odpowiadających wybranym genom zaangażowanym w odporność na choroby i szkodniki z roślin metodami analizy obliczeniowej i molekularnej. W ramach zadania $54 \mathrm{w}$ roku 2018 zrealizowano 4 tematy badawcze.

Celem tematu pierwszego było otrzymanie pokolenia $\mathrm{F}_{2} \mathrm{BC}_{2}$. Łącznie w 6 kombinacjach krzyżowania wstecznego zapylono 144 kwiaty, w wyniku czego otrzymano 59 łuszczyn i 62 nasiona. Płodność (\% stosunek zawiązanych łuszczyn do zapylonych kwiatów) oszacowana łącznie dla wszystkich kombinacji wyniosła $41 \%$, przy czym najwyższą płodność $(59,2 \%)$ obserwowano w przypadku zapylenia potomstwa (B. napus cv. Jet Neuf $\times B$. rapa $s s p$. pekinensis) pyłkiem pochodzącym z B. napus cv. Jet Neuf. Natomiast najniższą liczbę zawiązanych łuszczyn w stosunku do zapylonych kwiatów odnotowano dla kombinacji (B. napus cv. Lisek $\times$ B. tournefortii $) \times B$. napus $\mathrm{cv}$. Lisek $(25,0 \%)$. Generalnie współczynnik efektywności krzyżowania wstecznego wynosił $43 \%$. Ze względu na niski procent wiązania łuszczyn lub pojawianie się łuszczyn pustych w większości kombinacji krzyżowań wstecznych otrzymano małą liczbę prawidłowo rozwiniętych nasion.

Celem drugiego tematu badawczego było określenie odporności form mieszańcowych pokolenia $\mathrm{F}_{3} \mathrm{i}_{4} \mathrm{i}$ odmian rzepaku na porażenie przez Leptosphaeria maculans (sucha zgnilizna kapustnych) i Hyaloperonospora parasitica (mączniak rzekomy kapustnych) w warunkach polowych oraz w komorze klimatycznej, a także określenie zakresu zmienności istniejącej wśród odmian rzepaku ozimego oraz kombinacji mieszańcowych dotyczącej odporności na szkodniki takie jak: śmietka, pchełka i mszyca. Materiał badawczy stanowiło 46 odmian rzepaku ozimego oraz 25 kombinacji mieszańcowych pokoleń $\mathrm{F}_{3}$ i $_{\mathrm{F}}$ pochodzące z kolekcji KGiHR. Jesienią 2018 roku, sporadycznie odnotowywano na liściach rzepaku obecność objawów powodowanych przez mączniak rzekomy. Stwierdzono je jedynie na 4 odmianach, a porażenie wynosiło nie więcej niż $2 \%$. Aby oby ocenić odporność/podatność form mieszańcowych na $H$. parasitica przeprowadzono doświadczenie w kontrolowanych warunkach. W tym przypadku na wszystkich mieszańcach odnotowano objawy mączniaka rzekomego. Najsilniej porażone były rośliny mieszańcowe $B$. napus $c v$. Lisek $\times B$. tournefortii, a najsłabiej mieszańce otrzymane ze skrzyżowania $B$. napus z $B$. rapa ssp. pekinensis. Odsetek roślin porażonych przez grzyby z rodzaju Leptosphaeria był także niewielki i wahał się od 0 do 12,33\%. Nie stwierdzono symptomów suchej zgnilizny kapustnych na odmianie Andromeda, Arsenal i Graf, natomiast najsilniej porażona była odmiana Jupiter $(12,33 \%)$. Niewielkie porażenie stwierdzono także na formach mieszańcowych $(0 \%$ do $8,33 \%)$. Nie stwierdzono objawów powodowanych przez grzyby z rodzaju Leptosphaeria wśród mieszańców $B$. napus $\times B$. fruticulosa, $B$. napus $\times B$. carinata i $B$. napus $\times B$. rapa ssp. trilocularis. Natomiast najsilniej porażone były mieszańce $B$. napus $c v$. Californium $\times$ B. rapa ssp. chinensis i B. napus $c v$. Skrzeszowicki $\times$ B. rapa ssp. pekinensis 08006169. Wśród mieszańców pokolenia $F_{4}$ nadal obiecującym materiałem pod względem odporności na suchą zgniliznę kapustnych wydają się być mieszańce otrzymane $\mathrm{w}$ wyniku krzyżowania rzepaku z $B$. carinata i $B$. fruticulosa. Obserwacje wykonane na doświadczeniach kolekcyjnych KGiHR odnośnie występo- 
wania szkodników wykazały różne nasilenie ich występowania pomiędzy analizowanymi genotypami roślin. W Dłoni, jeden spośród trzech ocenianych szkodników, tj. śmietka kapuściana wystąpił w największym nasileniu. Natomiast sporadycznie obserwowano mszycę, a pchełki nie odnotowano wcale ani na testowanych odmianach ani na roślinach z pokoleń mieszańcowych.

Celem trzeciego tematu badawczego była cytogenetyczna analiza roślin mieszańcowych Brassica, z wykorzystaniem techniki fluorescencyjnej hybrydyzacji in situ (FISH) oraz określenie stopnia zróżnicowania genetycznego mieszańców z rodzaju Brassica na podstawie markerów ISSR. W 2018 roku przeanalizowano pięć kombinacji mieszańcowych Brassica (30 genotypów), w których formą mateczną był allotetraploidalny gatunek $B$. napus. Zastosowanie sekwencji rDNA (5S i 35S rDNA) pozwoliło na identyfikację chromosomów markerowych u form mieszańcowych Brassica pochodzących $\mathrm{z}$ genomów rodzicielskich - genom AA (B. rapa), genom CC (B. oleracea) oraz genom BB $(B$. nigra). Zastosowanie metody FISH pozwoliło na identyfikację chromosomów genomu $\mathrm{B}$ u mieszańców otrzymanych w wyniku krzyżowania $B$. napus $\times B$. carinata. Ponadto, przeprowadzone zostały analizy molekularne (ISSR) z zastosowaniem 30 starterów reakcji - 15 o potwierdzonej wysokiej polimorficzności (wybrane na podstawie wyników badań prowadzonych w 2017 r.) oraz 15 wybranych z literatury. Otrzymane wyniki wykazały małe zróżnicowanie genetyczne badanych genotypów mieszańcowych.

Temat badawczy $\mathrm{nr} \mathbf{4}$ dotyczył identyfikacji sekwencji dla znanych genów odporności na choroby i owady u wybranych roślin rodzicielskich i mieszańców Brassica z wykorzystaniem zaawansowanych technik molekularnych. W oparciu o dostępne dane literaturowe i analizy bioinformatyczne przeprowadzone w roku $2017 \mathrm{z}$ wykorzystaniem meta-serwera ORCAN, zdefiniowany został zestaw 30 genów ortologicznych, których funkcja jest związana $\mathrm{z}$ procesami odporności roślin na choroby i patogeny. W bieżącym roku wybrano sześć genów ortologicznych, których poszukiwano w analizowanym materiale roślinnym. Geny te stanowiły punkt wyjścia do identyfikacji odpowiadających im genów homologicznych lub genów najbardziej do nich zbliżonych pod względem podobieństwa sekwencji i/lub kompozycji i struktury domen białkowych. Poszukiwanie sekwencji genów ortologicznych stwarza poważny problem zwłaszcza dla gatunków $\mathrm{z}$ rodzaju Brassica, w tym rzepaku (B. napus) u których występuje znaczna homologia pomiędzy genomami rodzicielskimi. W związku $\mathrm{z}$ powyższym, na podstawie przeprowadzonych do tej pory analiz nie udało się w sposób jednoznaczny dokonać porównania sekwencji wybranych genów odporności u odpornego dawcy $B$. rapa i nieodpornych odmian rzepaku. 
